\title{
Theoretical and Experimental Heat of Combustion Analysis of Paraffin-Based Fuels as Preburn Characterization for Hybrid Rocket
}

Yash Pal ${ }^{1, *}$, Anthony Raja², Kavitha Gopalakrishnan ${ }^{3}$

Pal Y (D) https://orcid.org/0000-0003-2006-6202

Raja A (1) https://orcid.org/0000-0003-1301-6602

Gopalakrishnan K (1D https: / / orcid.org/0000-0002-7431-0955
How to cite

\begin{abstract}
Pal Y; Raja A; Gopalakrishnan K (2020) Theoretical and experimental heat of combustion analysis of paraffin-based fuels as preburn characterization for hybrid rocket. J Aerosp Technol Manag, 12: e4520. https://doi.org/10.5028/ jatm.v12.1180
\end{abstract}

ABSTRACT: The energy characteristics and theoretical performance of the hybrid rocket fuels are discussed in this paper. Aluminum (Al) and boron (B) metal additives were used to increase the energy density of the paraffin-based solid fuels. To predict the energy characteristics, the heat of combustion was evaluated by adiabatic bomb calorimetry. Theoretical performance parameters such as specific impulse $\left(I_{\mathrm{sp}}\right)$, flame temperature, and characteristic velocity were obtained with NASA Chemical Equilibrium with Applications (CEA) code. Calorimetric test results revealed that paraffin/polyethylene/boron ( $\mathrm{P} / \mathrm{PE} / \mathrm{B})$-based fuel formulations exhibited the highest heat of combustion among all the tested fuels. The heat of combustion value of the $\mathrm{P} / \mathrm{PE} / \mathrm{B}$ sample at $25 \mathrm{wt} \% \mathrm{~B}$ loading was found to be $9612 \pm 16 \mathrm{cal} / \mathrm{g}$ and $9293 \pm 17 \mathrm{cal} / \mathrm{g}$ for the P/PE/Al fuel formulation. The CEA results showed that the addition of $\mathrm{Al}$ to paraffin is noneffective in improving specific impulse performance. When $\mathrm{B}$ loading increased from 5 to $25 \mathrm{wt} \%$ in the $\mathrm{P} / \mathrm{PE} / \mathrm{B}$, the $I_{\mathrm{sp}}$ increased by $47 \mathrm{~s}$ compared to pure paraffin. A specific impulse increase implies the possible propellant mass saving. The reduction of the oxidizer and fuel masses may yield increased payload performance for given boundary conditions. The P/PE/B25 formulation has reported the highest value of characteristics velocity [C*] compared to other paraffin-based formulation.

KEYWORDS: Paraffin wax; Hybrid rocket; Heat of combustion; Specific impulse; Combustion flame temperature.

\section{INTRODUCTION}

The commercial satellite business is growing worldwide to build a low-cost and high-performance space launch vehicle capable of placing satellites in orbit. In the last few years, the nano/microsatellite launch market showed rapid growth with an average of 80 launches/year (Mazzetti et al. 2016). It is essential to identify a low-cost, safe handling, and reliable propulsion system for the commercial satellite operators. The hybrid rocket propulsion system has a low recurring cost compared to a solid counterpart and increased safety compared to the liquid rocket system. In hybrid rockets, the solid fuel does not contain any oxidizer, unlike solid propellant; therefore, the fuel is inert, which makes hybrid rockets comparatively safe. Thus, the hybrid propulsion system can be considered a potential candidate for suborbital and nanosatellite launch vehicles. In addition to their inherent safety, hybrid rockets feature several advantages, such as reignition capability, thrust modulation, insensitivity to fuel cracks, and nonhazardous

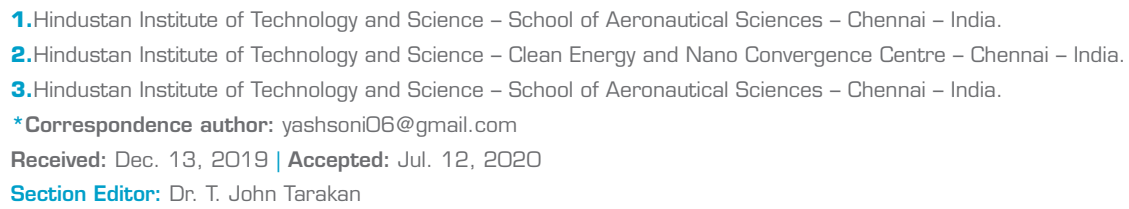


propellant combinations (Cantwell et al. 2010). The low regression rate and combustion efficiency are few drawbacks that prevent the practical use of hybrid rockets for suborbital flights and other space missions. The classical polymeric fuels (e.g. hydroxylterminated polybutadiene, HTPB) used in hybrid rockets suffer from a slow regression rate and results in low performance in terms of thrust.

Paraffin-based hybrid rocket fuels are characterized by a high regression rate, low cost, safety features, reliability, and low environmental impact. Larson et al. (1996) tested cryogenic fuels under gaseous oxygen. They found that the higher regression rates of these cryogenic propellant combinations were attributed to lower heat of vaporization and an additional mass transfer mechanism due to entrainment of liquid droplets at the surface of solid fuel. Karabeyoglu et al. (2004) explained the mechanism for the fast regression rate of liquefying fuels that develop a low viscosity melt layer over the fuel surface. Under the influence of the strong shear-stresses generated by the oxidizer flow, the melt layer over the fuel surface becomes unstable, and the paraffin droplets entrain toward the combustion zone. The resulting mass flow rate of the fuel in the combustion zone is composed of the paraffin droplets and oxidizer vapors.

This method of augmenting the regression rate is beneficial for specific applications. However, the paraffin-based fuels have lower combustion efficiency, and manufacturing of large fuel grain is difficult due to poor mechanical properties (DeSain et al. 2009; Maruyama et al. 2011; Kim et al. 2015; Kumar and Ramakrishna 2016). The poor combustion efficiencies of the hybrid rocket can be improved by adopting unique methods such as swirl injection, diaphragms, and postcombustion chamber design. Grosse (2009) achieved high combustion efficiency of paraffin-based fuel by using diaphragm located at various locations along the fuel grain. Carmicino et al. (2014) assessed the HTPB and paraffin motor performance under the gaseous oxygen and nitrous oxide oxidizers. It was reported that the paraffin-based fuels burnt more effectively with nitrous oxide than with oxygen. For upperstage launch vehicle applications, the fuel should possess high specific impulse and better mechanical properties than pure paraffin.

The high regression rate and better mechanical properties of paraffin-based solid fuels can be obtained by using correct fuel ingredients with virtuous physical and chemical properties. The selection of these fuel additives with optimum properties requires much precise information such as heat of combustion, density, melting point, and temperature of phase transition and decomposition.

In hybrid rocket combustion, the regression rate of solid fuel depends on the oxidizer mass flux, the ratio of mass flow to the port area, and the heat of gasification. The metallic additives can increase the regression rate by reducing the effective heat of gasification of the solid fuel. Since the polymeric fuel can vaporize at lower temperatures whereas the metal additive needs a very high temperature to vaporize. The solid fuel with the high heat of combustion can release a large amount of heat energy during combustion, which can vaporize more amount of fuel from the surface to the combustion zone (Sutton and Biblarz 2000). Also, the combustion performance of solid fuel is greatly affected by the fuel properties (Gany 2006).

The energetic performance parameter of a fuel formulation can be considered as a specific impulse, which is related to the heat of combustion (Gany 2006). Higher heat of combustion results in higher specific impulse, and a brief discussion about the effect of the heat of combustion on specific impulse can be found in Gany (2006). The addition of metallic additives in solid fuel depresses the specific impulse performance for hybrid rocket (Risha et al. 2002; 2003; Connell Junior et al. 2013; Jaffe et al. 2013; Dermanci and Karabeyoglu 2015). This performance parameter is directly related to the molecular weight of the combustion products. The metallic fuel increases the molecular weight of combustion products and decreases specific impulse performance. However, the addition of additives improves the density, which contributes to obtaining a higher mass burning rate. Paravan et al. (2019) investigated the effect of active aluminum content and reactivity on the flame temperature and theoretical vacuum specific impulse of an aluminized solid propellant. It was reported that the theoretical vacuum specific impulse of the metalized propellant formulations varied linearly with active aluminum content. Also, the results showed that the reactivity of metal powder displayed a significant effect on the formation of aggregates/agglomerates and burn rates of condensed materials.

Many researchers have attempted to improve the mechanical properties of paraffin-based fuels. Several additives such as polyethylene (PE) (DeSain et al. 2009; Kim et al. 2015), ethylene-vinyl acetate (EVA) (Maruyama et al. 2011; Kumar and Ramakrishna 2016) and carbon black (CB) powder (Karabeyoglu et al. 2001) were used in paraffin to improve its mechanical properties and combustion efficiency. The addition of $\mathrm{PE}$ in paraffin wax can improve the mechanical properties and combustion efficiency, whereas the addition of metal additives is expected to raise the heat transfer from the flame zone to the fuel surface 
(Kim et al. 2015). Veale et al. (2017) performed an extensive review of existing regression rate data of paraffin-based fuel and discussed various testing techniques to enhance combustion and mechanical performance. It was reported that the poor mechanical performance of paraffin could be improved with the addition of various metallic and polymeric additives. The modification of paraffin through polymeric additives such as high-density polyethylene (HDPE), low-density polyethylene (LDPE), stearic acid (SA), ethylene-vinyl acetate copolymer (EVA), and polyethylene wax, polypropylene (PP) can enhance mechanical properties besides declining the regression rate performance (Tang et al. 2017).

Other applications of paraffin wax as solid fuel could be in ramjet engines. Azevedo et al. (2019) tested paraffin wax solid fuel on a lab-scale ramjet motor in a supersonic air environment. They developed a correlation between the regression rate and oxidizer mass flux through a power low at the conditions of Mach 2.5 and $10 \mathrm{~km}$ altitude. However, their results indicated that the poor combustion of paraffin and low combustion efficiency.

Di Martino et al. (2019) at the University of Naples "Federico II" characterized paraffin-based fuels for regression rate performance under both a lab-scale 200-N thrust motor and a larger-scale 1000-N thrust motor. It was reported that the regression rate scaling up depends on several parameters such as injector-to-port diameter ratio, injector designs beside highly depends on oxidizer mass flux. Chen et al. (2019) attempted to improve the combustion performance of the HTPB-based solid fuels by adding low-energy polymer particles. The poor mechanical properties of paraffin-based fuel were enhanced through the self-disintegration fuel structure (SDFS) technique.

Calorimetry is a preburning characteristic method to evaluate the energetic characteristic of fuel formulation. This method is more accurate, very effective, and reliable to estimate the heat content of solid fuels and explosives (Jawale et al. 2013). The effect of metal additives on the heat of combustion of solid hybrid rocket fuels has not been extensively studied and only limited information on the heat of combustion is available. Whitmore et al. (2011) have studied the heat of combustion of HTPB and acrylonitrilebutadiene-styrene (ABS) hybrid fuels. Their results indicated that the heat of combustion of HTPB fuel was about 42.64 and $39.60 \mathrm{~kJ} / \mathrm{kg}$ for ABS fuel. The effect of solid fuel aging on the heat of combustion and ignition temperature was studied by Kishore et al. $(1982 ; 1986)$. The heat of combustion and ignition temperatures of the HTPB-based solid fuels have decreased with increasing aging duration. Walters et al. (2000) conducted bomb calorimeter experiments with high-temperature polymers to study the heat of combustion.

Therefore, a study is required to understand the couple binder-additive effect of PE-metal additives, the heat of combustion study as preburn characterization, mechanical properties, and ballistics performance should be dedicated to upgrade the performance of paraffin-based fuel for hybrid propulsion. Recently, the mechanical performance tests were performed on these paraffin-based fuels and it was found that the addition of polymer binder and metallic additives improved the tensile and elastic modulus (Pal and Ravikumar 2019). Wang et al. (2006) demonstrated the enhancement of stiffness, strength, and toughness of the paraffin matrix through the addition of organoclay. The improvement was attributed to the toughening mechanism, which displayed the adhesion of short-chain n-alkanes of paraffin wax to the alkyl chains to the surfaces of clay platelets. Kobald et al. (2014) reported that the tensile strength and elongation were significantly improved when SA and nanoclay in small amounts were added to the paraffin.

The objective of this study is to explore the energy characteristics and theoretical performance of paraffin-based fuels containing $\mathrm{B}$ and $\mathrm{Al}$ additives. The heat of combustion as preburning characterization was carried out to understand the effect of metallic additive on the heat of combustion performance. Theoretical performance was studied using NASA CEA (McBride and Gordon 1996). The performance parameters such as theoretical specific impulse, flame temperature, molecular weight of combustion products, and characteristic velocity were evaluated.

\section{EXPERIMENTAL}

\section{MATERIALS}

In the current study, the paraffin wax (melting point $=59^{\circ} \mathrm{C}$, molecular weight $=380 \mathrm{~g} / \mathrm{mol}$, density $=0.920 \mathrm{~g} / \mathrm{cm}^{3}$ at $25^{\circ} \mathrm{C}$ ) was supplied by Merck India and used as fuel. The PE (melting point $=104^{\circ} \mathrm{C}$, density $=0.918 \mathrm{~g} / \mathrm{cm}^{3}$ ) was supplied from Merck 
India. The $\mathrm{B}$ and $\mathrm{Al}$ with purity $=99.5 \%$ and size between $0.5-43 \mu \mathrm{m}$, manufactured by NR Chemical Bombay, were used in this study. The density of B particles was $2.37 \mathrm{~g} / \mathrm{cm}^{3}$ and $2.7 \mathrm{~g} / \mathrm{cm}^{3}$ for Al particles.

The $\mathrm{Al}$ and $\mathrm{B}$ metal powders were used to increase the energy density of solid fuels. In Fig. 1a, scanning electron microscope (SEM) analysis reveals that most of the Al particles are nearly spherical; however, few are granular. The particle diameter ranges from 0.5 to $35 \mu \mathrm{m}$ and the average particle diameter (D43) are $6.5 \mu \mathrm{m}$, as shown in Fig. 2a. Figure $1 \mathrm{~b}$ shows that the B particles are spherical. These particles have diameters less than $43 \mu \mathrm{m}$ with an average diameter (D43) of $8.1 \mu \mathrm{m}$, as shown in Fig. $2 \mathrm{~b}$. The benzoic acid of AR grade was used for the standardization of the bomb calorimeter. A pellet press was used to make $1.0 \mathrm{~g}$ of the benzoic acid pellet. The oxygen gas (99.99\% pure) used in the present study had moisture and total hydrocarbon contents below 1 ppm.

(a)

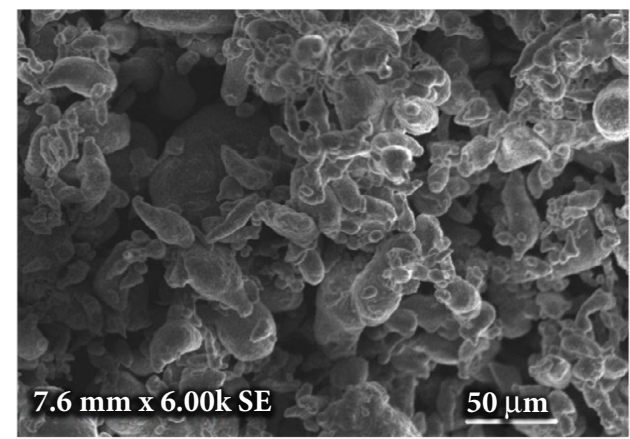

(b)

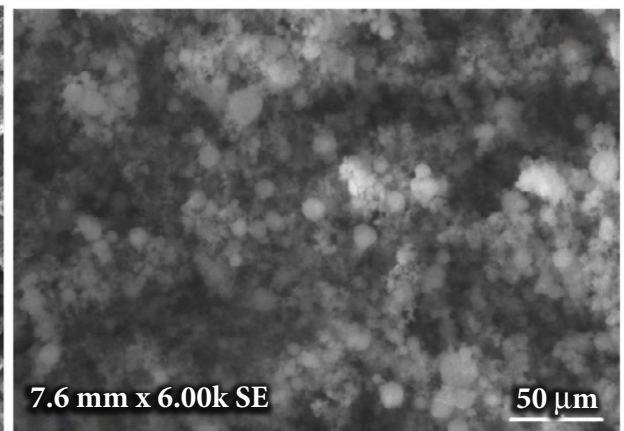

Figure 1. SEM image of additives: (a) aluminum; (b) boron.

(a)

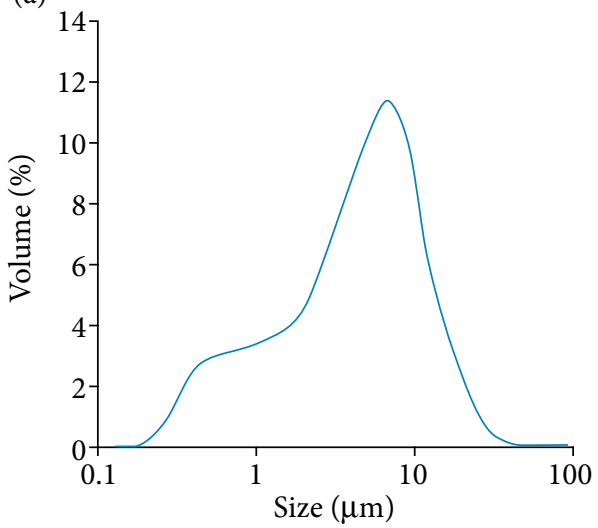

(b)

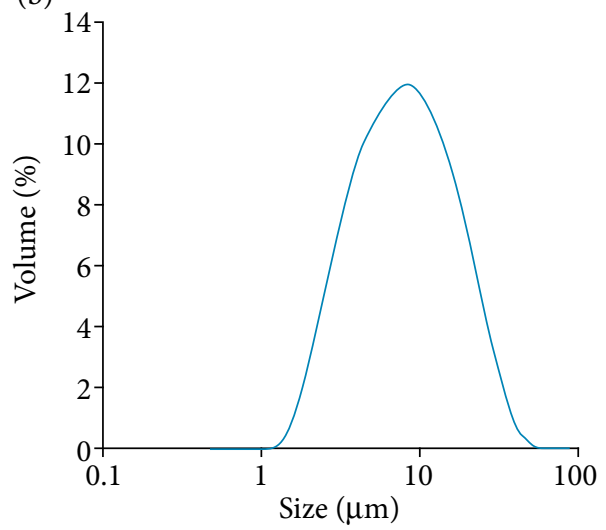

Figure 2. Particle size distribution: (a) aluminum and (b) boron.

\section{INSTRUMENTATION}

A bomb calorimeter, ParrModel 1108, manufactured by Parr Instrument Company, was used to measure the heat of combustion of the paraffin-based solid fuels. The combustion bomb of the calorimeter is capable of withstanding a hydrostatic pressure of $20 \mathrm{MPa}$ at room temperature. Nichrome ignition wire of known specific heat, $2.3 \mathrm{cal} / \mathrm{cm}$, was used for sample ignition. A pellet press was used to compress the sample into a compact form to ensure the complete combustion of the sample. All the calorimetric experiments were performed under isothermal conditions.

\section{SAMPLE PREPARATION}

The standardization of bomb calorimeter was carried out using the commercially available standard benzoic acid powder. The standard benzoic acid pellets were prepared using a pellet press as per the ASTM D240 standard (ASTM 2019). The paraffin-based 
fuels were prepared by melting the pure paraffin wax and polyethylene in a pan. The addition of metal additives to solid fuel is a commonly used technique to improve the regression rate performance and fuel density. In this study, the loading limit of metal additives in solid fuel is limited to $25 \%$, since at high metallic loading the combustion near the fuel surface becomes less efficient due to accumulation of particles at the fuel surface (Evans et al. 2007). This ultimately results in reduced heat transfer and low regression rate performance. The respective metal additive was dispersed to molten paraffin and polyethylene blend. The mixture was magnetically stirred for $30 \mathrm{~min}$ to ensure homogeneous distribution of additives. The mixture was poured in casting tubes rapidly and allowed for slower cooling (suitable thermal gradient using water bath) and solidification for $3 \mathrm{~h}$ under vacuum to remove trapped air in the paraffin. Since the paraffin tends to shrink in volume when transitioning from liquid to solid, a suitable thermal gradient was maintained across the mold to prevent the formation of internal cracks or defects due to shrinkage. The paraffin-based solid fuel samples used for this study are presented in Table 1.

Table 1. Composition of paraffin-based solid fuels.

\begin{tabular}{|c|c|}
\hline Fuel sample & Composition \\
\hline Pure paraffin & paraffin $100 \%$ \\
\hline P/PE & paraffin $90 \%+$ polyethylene $10 \%$ \\
\hline P/PE/B5 & paraffin $85 \%+$ polyethylene $10 \%+$ boron $5 \%$ \\
\hline P/PE/B15 & paraffin $75 \%+$ polyethylene $10 \%+$ boron $15 \%$ \\
\hline P/PE/B25 & paraffin $65 \%+$ polyethylene $10 \%+$ boron $25 \%$ \\
\hline P/PE/Al5 & paraffin $85 \%+$ polyethylene $10 \%+$ aluminum $5 \%$ \\
\hline P/PE/Al15 & paraffin $75 \%+$ polyethylene $10 \%+$ aluminum $15 \%$ \\
\hline P/PE/Al25 & paraffin $65 \%+$ polyethylene $10 \%+$ aluminum $25 \%$ \\
\hline
\end{tabular}

\section{TESTING PROCEDURE}

\section{Standardization of bomb calorimeter}

The standardization of the bomb calorimeter was carried out with benzoic acid to determine the energy equivalent of the calorimeter. The energy equivalent of the calorimeter was determined by Eq. 1.

$$
W_{e q}=\frac{h_{c o m} \times w+\left(C_{f}+C_{a}\right)}{\Delta T_{c r}}
$$

where, $h_{\text {com }}$, is the heat of combustion of benzoic acid in $(\mathrm{cal} / \mathrm{g}), w$ is the weight of benzoic acid in $(\mathrm{g}), C_{f}$ is the fuse-wire correction, $\Delta T_{c r}$, corrected temperature rise and $C_{a}$ is the acid correction.

The temperature rise during the sample combustion was measured with an accuracy of $0.003{ }^{\circ} \mathrm{C}$. The temperature rise was corrected for thermal leakage and loss of heat during water stirring in the bomb jacket. Therefore, the temperature of calorimeter is measured at three definite time intervals (initial, main and equilibrium zone) and corrected temperature rise is obtained from Eq. 2.

$$
\Delta T_{c r}=T_{n}-T_{0}+c
$$

where, $T_{n}$, is the last value of temperature in the main period, $T_{0}$ is the last value of temperature in the initial period, $c$ is the correction factor for heat exchange between calorimeter and surrounding. The correction factor $\mathrm{c}$ is calculated by Bunte's Eq. 3. 


$$
c=N_{t}\left[\left(\Delta T_{i}+\Delta T_{f}\right)+n \Delta T_{f}\right]
$$

where $N_{t}$ is a number of temperature points recorded per minute, $\Delta T_{i}$ is a mean value of temperature increase $\left({ }^{\circ} \mathrm{C}\right)$ per one minute during the initial period, $\Delta T_{f}$ is a mean value of temperature decrease $\left({ }^{\circ} \mathrm{C}\right)$ per one minute during the final period, $\mathrm{n}$ is a number of temperature points recorded during the main period.

After the calorimeter test, the interior surface of the bomb was washed with a jet of distilled water and bomb washing was titrated against $0.0709 \mathrm{~N}$ sodium carbonate solution. The amount of solution $(\mathrm{ml})$ after titrated is the value of acid correction in calories. The correction for the ignition wire is obtained by measuring the length of the un-burnt wire after the test. The calorific value of the nichrome ignition wire was calculated as $2.3 \mathrm{cal}$ per centimetre of a burned ignition wire.

\section{Determination of calorific value of paraffin-based solid fuels}

The heat of combustion of paraffin-based solid fuels was determined by Eq.4:

$$
H_{c o m}=\frac{\left(W_{e q} \times \Delta T_{c r}-C_{f}-C_{a}\right)}{w_{f}}
$$

where, $H_{c o m}$ and $w_{f}$ are the heat of combustion (cal/g) and weight (g) of solid fuel. In order to establish the repeatability of the test, each formulation was tested three times.

\section{CEA THEORETICAL PERFORMANCE}

Theoretical specific impulse, flame temperature, characteristic velocity, and molecular weight of combustion products are few important parameters of solid fuel, which need critical attention during the selection of fuel formulation. These theoretical performance parameters can be evaluated using the NASA CEA. Therefore, a thermochemical assessment was carried out to estimate the theoretical performance of paraffin-based solid fuel. Each solid fuel was simulated under the ideal operating condition and nozzle expansion ratio (40) over an oxidizer to fuel ratio (0.5-8). All calculations were performed with vacuum expansion and shifting equilibrium conditions. The gaseous oxygen was selected as an oxidizer. The initial temperature of each fuel component $\left(\mathrm{C}_{31} \mathrm{H}_{64}\right.$-paraffin) and oxidizer was set at $25^{\circ} \mathrm{C}$. The simulation was carried out by varying the $\mathrm{O} / \mathrm{F}$ ratio.

Hybrid rocket performance parameters sensitive to chamber pressure was thoroughly discussed by several researchers (Evans et al. 2007; Cantwell et al. 2010; Shark et al. 2013). The relationship between chamber pressure and specific impulse/flame temperature is nontrivial, whereas its dependency on the regression rate of the solid fuel is small (Altman and Holzman 2007). Therefore, in this study, the CEA calculations were performed at two combustion pressures to study its effect on performance parameters. The first combustion pressure was selected as $1 \mathrm{MPa}$, since in typical small experimental lab-scale motor the lower operating chamber pressure corresponds to this value. In order to have a valid assessment of theoretical performance parameters, the second combustion pressure range was selected as $3 \mathrm{MPa}$ (typical operating combustion chamber pressure in hybrid rockets).

\section{RESULTS AND DISCUSSION}

\section{STANDARDIZATION OF BOMB CALORIMETER}

The experiments were performed for the standardization of bomb calorimeter, and results are summarized in Table 2 . The mean value of water equivalent after ignition wire correction and an acid correction was found to be $2439 \pm 37 \mathrm{cal} / \mathrm{g}$. This corrected value of water equivalent was considered as standard value for calculation of heat of combustion of the paraffin-based solid fuels. 
Table 2. Test data of standardization of bomb calorimeter.

\begin{tabular}{|c|c|c|c|c|c|c|}
\hline $\begin{array}{l}\text { Test } \\
\text { No. }\end{array}$ & $\begin{array}{c}\text { Sample } \\
\text { weight } \\
w_{f}, \text { [g] }\end{array}$ & $\begin{array}{c}\text { Corrected } \\
\text { temperature rise } \\
\Delta T_{c},\left({ }^{\circ} \mathrm{C}\right]\end{array}$ & $\begin{array}{c}\text { Heat of } \\
\text { combustion } \\
h_{c o m},[\text { cal } / g]\end{array}$ & $\begin{array}{l}\text { Acid } \\
\text { correction } \\
\text { [cal] }\end{array}$ & $\begin{array}{l}\text { Ignition wire } \\
\text { correction } \\
\text { [cal] }\end{array}$ & $\begin{array}{c}\text { Corrected } \\
\text { water equivalent } \\
\text { (cal } /{ }^{\circ} \mathrm{C} \text { ] }\end{array}$ \\
\hline 1 & 0.92 & 2.4586 & 6324 & 6.1 & 16.3 & 2401 \\
\hline 2 & 0.97 & 2.4775 & 6324 & 6.5 & 12.8 & 2484 \\
\hline 3 & 0.93 & 2.4502 & 6324 & 6.7 & 12.1 & 2408 \\
\hline 4 & 0.92 & 2.4257 & 6324 & 7.2 & 14.1 & 2407 \\
\hline 5 & 0.96 & 2.4562 & 6324 & 7.1 & 12.4 & 2479 \\
\hline 6 & 0.94 & 2.4715 & 6324 & 8.1 & 11.2 & 2413 \\
\hline 7 & 0.93 & 2.4315 & 6324 & 6 & 12.1 & 2426 \\
\hline 8 & 0.95 & 2.4451 & 6324 & 6.7 & 14.1 & 2466 \\
\hline 9 & 0.96 & 2.4421 & 6324 & 7.6 & 13.3 & 2494 \\
\hline 10 & 0.94 & 2.4726 & 6324 & 7.4 & 16.1 & 2414 \\
\hline \multicolumn{6}{|c|}{ Average } & 2439 \\
\hline \multicolumn{6}{|c|}{ SD } & 37 \\
\hline
\end{tabular}

During the measurement of corrected temperature rise, undesirable side reactions, incomplete combustion, and oxidation reactions at crucible may take place in the combustion bomb. Therefore, these factors can affect the water equivalent value during the measurement. For the precise measurement of corrected temperature rise, it is necessary to eliminate all thermal leakage corrections. In the current study, the temperature measurements were carried out at definite three-time intervals: an initial period of 0 to 4 min corresponding to temperature change due to heat of stirring and thermal leakage as shown in Fig. 3; main temperature zone of about 4 to $13 \mathrm{~min}$ during which the oxidation reactions liberated the most of heat; and an equilibrium temperature zone of about $6 \mathrm{~min}$ or more during which the temperature remained constant.

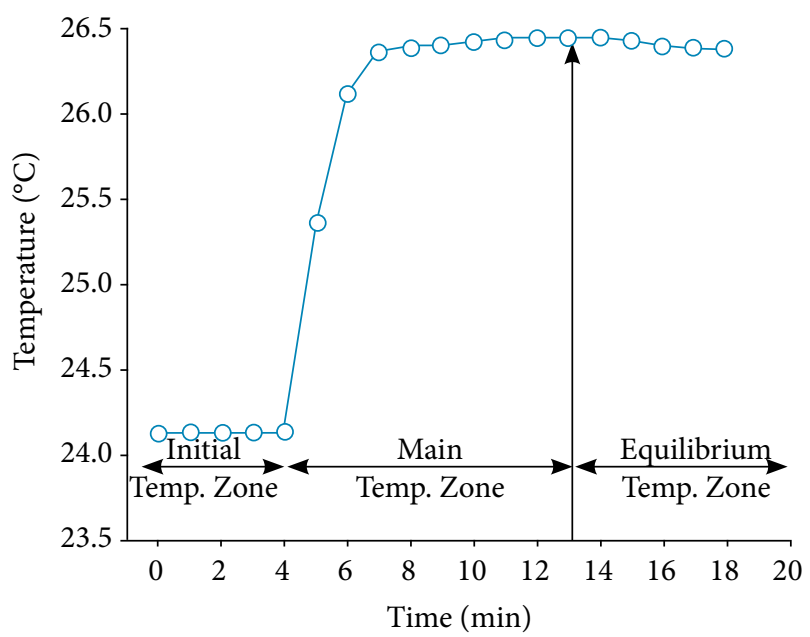

Figure 3. Temperature vs time profile of the benzoic acid sample. 


\section{HEAT OF COMBUSTION OF THE PARAFFIN-BASED SOLID FUELS}

The heat of combustion of the paraffin-based fuels was evaluated using pure oxygen as oxidizer and results are presented in Fig. 4. The average heat of combustion value for pure paraffin wax was found to be $8105 \pm 55.1 \mathrm{cal} / \mathrm{g}$ and $8223 \pm 50.6 \mathrm{cal} / \mathrm{g}$ for P/PE10 sample (Table 3). The addition of PE to pure paraffin wax increased the heat of combustion. The higher heat of combustion value of the $\mathrm{PE}$ in $\mathrm{P} / \mathrm{PE}$ blend is responsible for increased heat of combustion of the $\mathrm{P} / \mathrm{PE}$ sample (Walters et al. 2000).

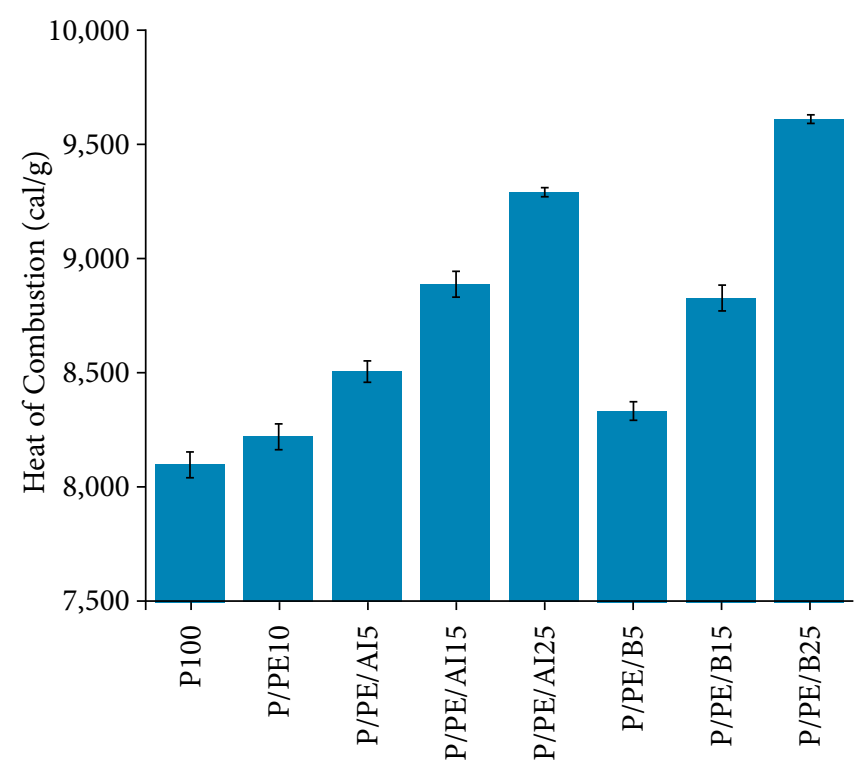

Figure 4. Heat of combustion comparison for paraffin-based solid fuels.

Table 3. Test data of paraffin wax and P/PE solid fuel.

\begin{tabular}{|c|c|c|c|c|c|c|}
\hline $\begin{array}{l}\text { Test } \\
\text { No. }\end{array}$ & Sample & $\begin{array}{l}\text { Sample weight } \\
\qquad w_{f}[g]\end{array}$ & $\begin{array}{c}\text { Corrected } \\
\text { temperature rise } \\
\Delta T_{c}\left({ }^{\circ} \mathrm{C}\right]\end{array}$ & $\begin{array}{l}\text { Acid correction } \\
\text { [cal] }\end{array}$ & $\begin{array}{l}\text { Ignition wire } \\
\text { correction [cal] }\end{array}$ & $\begin{array}{c}\text { Heat of } \\
\text { combustion } \\
h_{c o m} \text {, }[\text { cal } / g \text { ] }\end{array}$ \\
\hline 1 & \multirow{3}{*}{$\begin{array}{l}\text { paraffin } \\
\text { wax }\end{array}$} & 1.01 & 3.363 & 6.0 & 17.1 & 8099 \\
\hline 2 & & 1.00 & 3.357 & 6.8 & 18.6 & 8163 \\
\hline 3 & & 1.01 & 3.345 & 7.2 & 17.9 & 8053 \\
\hline \multicolumn{6}{|c|}{ Average } & 8105 \\
\hline \multicolumn{6}{|c|}{ SD } & 55.1 \\
\hline 1 & \multirow{3}{*}{ P/PE10 } & 1.02 & 3.426 & 6.7 & 17.5 & 8169 \\
\hline 2 & & 1.01 & 3.434 & 8.1 & 15.9 & 8270 \\
\hline 3 & & 1.01 & 3.415 & 6.1 & 11.9 & 8230 \\
\hline \multicolumn{6}{|c|}{ Average } & 8223 \\
\hline \multicolumn{6}{|c|}{ SD } & 50.6 \\
\hline
\end{tabular}

The paraffin-based solid fuels were also tested with metallic additives. The metallic $\mathrm{Al}$ was added in the $\mathrm{P} / \mathrm{PE}$ blend ranging from 5 to $25 \mathrm{wt} \%$. Each solid fuel formulation was tested three times, and the average values of the heat of combustion are presented in Table 4. The addition of $\mathrm{Al}$ additive increased the heat of the combustion of $\mathrm{P} / \mathrm{PE} / \mathrm{Al}$ formulations. The $\mathrm{P} / \mathrm{PE} /$ 
Al25 formulation with $25 \mathrm{wt} \%$ Al loading had shown the highest heat of combustion of about $9293 \pm 16.8 \mathrm{cal} / \mathrm{g}$. Figure 4 shows that the addition of PE $(\sim 10 \mathrm{wt} \%)$ in paraffin wax increased the heat of combustion about $1.2 \%$ compared to pure paraffin wax. It was also noticed that by increasing Al doping from 5 to $25 \%$, the increment in the heat of combustion was about $9.2 \%$. A total increment of $14.6 \%$ in the heat of combustion was observed with P/PE/Al25 formulation compared to the pure paraffin wax sample.

The heat of combustion tests was also performed with $\mathrm{P} / \mathrm{PE} / \mathrm{B}$ formulation. Table 5 shows the heat of the combustion value of the $\mathrm{P} / \mathrm{PE} / \mathrm{B}$ formulation to be $8335 \pm 39 \mathrm{cal} / \mathrm{g}$ with a B loading of $5 \mathrm{wt} \%$. At $25 \mathrm{wt} \% \mathrm{~B}$ loading, it was found that the heat of combustion increased to $9612 \pm 15.9 \mathrm{cal} / \mathrm{g}$. Figure 4 clearly shows that the heat of combustion of P/PE/B formulation increased by about $15.3 \%$ when the B loading increased from 5 to $25 \mathrm{wt} \%$. A total increment of $19 \%$ in the heat of combustion is observed with $\mathrm{P} / \mathrm{PE} / \mathrm{B} 25$ formulation compared to pure paraffin wax sample.

The comparison of the theoretical value and experimental value of heat of combustion of the paraffin-based fuels are presented in Table 3. Collected data show that the experimental value of heat of combustion for all paraffin-based fuel formulations has a significant difference (about 7.2 to 19.5\%) with the theoretical value. The difference in heat of combustion can be ascribed to fact that the experimental heat of combustion is measured at a constant volume, whereas the theoretical calculation performed by the CEA code is based on constant pressure heat of combustion. The relationship between constant pressure heat of combustion and constant volume heat of combustion is given by Eq. 5 (Jiawang et al. 2014).

Table 4. Test data of $P / P E / A l$ solid fuel formulation.

\begin{tabular}{|c|c|c|c|c|c|c|}
\hline $\begin{array}{l}\text { Test } \\
\text { No. }\end{array}$ & Sample & $\begin{array}{l}\text { Sample weight, } \\
\qquad w_{f},[g]\end{array}$ & $\begin{array}{c}\text { Corrected } \\
\text { temperature rise } \\
\Delta \mathrm{T}_{\mathrm{c},}\left[{ }^{\circ} \mathrm{C}\right]\end{array}$ & $\begin{array}{l}\text { Acid correction } \\
\text { [cal] }\end{array}$ & $\begin{array}{l}\text { Ignition wire } \\
\text { correction } \\
\text { [cal] }\end{array}$ & $\begin{array}{c}\text { Heat of } \\
\text { combustion } \\
h_{\text {com }},[\mathrm{cal} / \mathrm{g}]\end{array}$ \\
\hline 1 & \multirow{3}{*}{$\mathrm{P} / \mathrm{PE} / \mathrm{Al} 5$} & 0.99 & 3.458 & 9.4 & 17.5 & 8494 \\
\hline 2 & & 0.98 & 3.449 & 8.4 & 16.1 & 8561 \\
\hline 3 & & 0.99 & 3.445 & 8.8 & 13.6 & 8467 \\
\hline \multicolumn{6}{|c|}{ Average } & 8507 \\
\hline \multicolumn{6}{|c|}{ SD } & 48.5 \\
\hline 1 & \multirow{3}{*}{ P/PE/Al15 } & 0.95 & 3.493 & 7.9 & 14.5 & 8946 \\
\hline 2 & & 0.95 & 3.476 & 7.3 & 13.1 & 8903 \\
\hline 3 & & 0.96 & 3.483 & 7.1 & 11.1 & 8831 \\
\hline \multicolumn{6}{|c|}{ Average } & 8893 \\
\hline \multicolumn{6}{|c|}{ SD } & 58.1 \\
\hline 1 & \multirow{3}{*}{$\mathrm{P} / \mathrm{PE} / \mathrm{Al} 25$} & 0.92 & 3.508 & 7.1 & 12.9 & 9280 \\
\hline 2 & & 0.92 & 3.520 & 6.9 & 12.4 & 9312 \\
\hline 3 & & 0.92 & 3.510 & 6.6 & 11.7 & 9286 \\
\hline \multicolumn{6}{|c|}{ Average } & 9292 \\
\hline \multicolumn{6}{|c|}{ SD } & 16.8 \\
\hline
\end{tabular}

$$
\Delta H_{(\mathrm{comb})_{p}}=\Delta H_{(\mathrm{comb})_{v o l}}+\Delta n R T
$$


Since the experiments were performed at $3 \mathrm{MPa}$, heat of the released gas was omitted in the combustion reaction. The quantity of gas released during combustion was minimal compared to $3 \mathrm{MPa}$. If the gas released during the combustion is nonignorable, the value of the second term in Eq. 5 would be large (Jiawang et al. 2014). During the experimental heat of combustion calculation, the constant volume heat of combustion was approximated to the constant pressure heat of combustion.

Table 5. Test data of $\mathrm{P} / \mathrm{PE} / \mathrm{B}$ solid fuel formulation.

\begin{tabular}{|c|c|c|c|c|c|c|}
\hline $\begin{array}{l}\text { Test } \\
\text { No. }\end{array}$ & Sample & $\begin{array}{l}\text { Sample weight } \\
\left.\qquad w_{f}, g\right]\end{array}$ & $\begin{array}{c}\text { Corrected } \\
\text { temperature rise } \\
\Delta \mathrm{T}_{\mathrm{c},}\left[{ }^{\circ} \mathrm{C}\right]\end{array}$ & $\begin{array}{c}\text { Acid correction } \\
\text { [cal] }\end{array}$ & $\begin{array}{l}\text { Ignition wire } \\
\text { correction } \\
\text { [cal] }\end{array}$ & $\begin{array}{c}\text { Heat of } \\
\text { combustion } \\
h_{c o m},[c a l / g]\end{array}$ \\
\hline 1 & \multirow{3}{*}{$\mathrm{P} / \mathrm{PE} / \mathrm{B} 5$} & 1.00 & 3.412 & 10.4 & 16.3 & 8295 \\
\hline 2 & & 0.99 & 3.396 & 9.9 & 17.5 & 8338 \\
\hline 3 & & 1.01 & 3.478 & 9.6 & 16.3 & 8373 \\
\hline \multicolumn{6}{|c|}{ Average } & 8335 \\
\hline \multicolumn{6}{|c|}{ SD } & 39.0 \\
\hline 1 & \multirow{3}{*}{$\mathrm{P} / \mathrm{PE} / \mathrm{B} 15$} & 0.99 & 3.621 & 8.6 & 16.3 & 8895 \\
\hline 2 & & 0.98 & 3.538 & 8.4 & 14.9 & 8781 \\
\hline 3 & & 1.00 & 3.624 & 7.9 & 13.6 & 8817 \\
\hline \multicolumn{6}{|c|}{ Average } & 8831 \\
\hline \multicolumn{6}{|c|}{ SD } & 58.0 \\
\hline 1 & \multirow{3}{*}{$\mathrm{P} / \mathrm{PE} / \mathrm{B} 25$} & 0.90 & 3.561 & 8.1 & 14.1 & 9627 \\
\hline 2 & & 0.90 & 3.556 & 7.3 & 11.7 & 9616 \\
\hline 3 & & 0.90 & 3.548 & 7.2 & 11.3 & 9595 \\
\hline \multicolumn{6}{|c|}{ Average } & 9612 \\
\hline \multicolumn{6}{|c|}{ SD } & 15.9 \\
\hline
\end{tabular}

The addition of $\mathrm{B}$ and $\mathrm{Al}$ metal additives enhanced the heat of combustion. This behavior can be attributed to large heat produced by metal particles during the combustion. The metal additives increase the gas phase temperature, which leads to an increase in adiabatic flame temperature and improves the heat of combustion. The gravimetric heat of combustion for several metal additives with HTPB binder combination was studied by Risha et al. $(2002 ; 2003)$, who concluded that B and Al are the best promising candidates for solid fuel among all metal additives. Besides, the combustion efficiency $\left(\eta_{c}\right)$ based on the experimental heat of combustion and theoretical heat of combustion was calculated and presented in Table 6 . The addition of Al and B additives has increased combustion efficiency. This indicates that the additives released higher heat during the combustion and enhanced the oxidation reaction of fuel.

The $\mathrm{P} / \mathrm{PE} / \mathrm{B}$ fuel formulation exhibited low combustion efficiency compared to other fuel formulation. It may be because $\mathrm{P} / \mathrm{PE} / \mathrm{B}$ formulations were combusted at low pressure and caused incomplete combustion of B particles. During the initial stage of heating, the core B-particles are coved with a B-oxide layer and melts at relatively low temperatures (750 K) (Gany 2014). This protective oxide layer prevents the radiative heat transfer to solid fuel surface, and the net result is a relative decrease in the heat of combustion 
of $\mathrm{P} / \mathrm{PE} / \mathrm{B}$ formulations. The $\mathrm{B}$ oxide layer does not allow the full diffusion of oxygen to $\mathrm{B}$ core, thus hindering its ignition and combustion at low temperature and pressure. The complete combustion of B can be sustained at high temperature when the protective oxide layer breaks and permit the chemical reaction between core B and oxidizer (Gany 2014). The flame temperature depends on the energetic and chemical properties of fuel (particularly heat of combustion). The higher heat of combustion can yield the high flame temperature, which in turn degrades more fuel from the surface and generate more mass flow rate through the nozzle.

Table 6. Heat of combustion of paraffin-based solid fuels.

\begin{tabular}{|c|c|c|c|c|c|}
\hline \multirow[b]{2}{*}{ Fuel samples } & \multicolumn{4}{|c|}{ Heat of combustion, (cal/g), at $3 \mathrm{MPa}$} & \multirow[b]{2}{*}{$\begin{array}{l}\text { SD } \\
\text { [\%] }\end{array}$} \\
\hline & $\begin{array}{c}\text { Theoretical } \\
\text { [CEA] }\end{array}$ & $\begin{array}{c}\text { Experimental } \\
\text { [bomb } \\
\text { calorimetry] }\end{array}$ & $\begin{array}{c}\mathrm{SD} \\
\text { [cal/g] }\end{array}$ & $\begin{array}{l}\text { Combustion } \\
\text { efficiency } \eta_{c}\end{array}$ & \\
\hline P100 & 9689 & 8105 & 55.1 & 84 & 1.5 \\
\hline P/PE10 & 9755 & 8223 & 50.6 & 84 & 1.8 \\
\hline $\mathrm{P} / \mathrm{PE} / \mathrm{Al} 5$ & 9795 & 8507 & 48.5 & 87 & 1.2 \\
\hline $\mathrm{P} / \mathrm{PE} / \mathrm{Al} 15$ & 9835 & 8893 & 58.1 & 90 & 2.1 \\
\hline $\mathrm{P} / \mathrm{PE} / \mathrm{Al} 25$ & 9970 & 9293 & 16.8 & 93 & 1.3 \\
\hline $\mathrm{P} / \mathrm{PE} / \mathrm{B} 5$ & 9756 & 8335 & 39.0 & 85 & 1.1 \\
\hline $\mathrm{P} / \mathrm{PE} / \mathrm{B} 15$ & 10253 & 8831 & 58.0 & 86 & 1.7 \\
\hline $\mathrm{P} / \mathrm{PE} / \mathrm{B} 25$ & 10895 & 9612 & 15.9 & 88 & 1.4 \\
\hline
\end{tabular}

Moreover, when considering the metallic additives in the fuel formulations, the radiation heat transfer plays a crucial role in enhancing the fuel vaporization from the fuel surface. For nonmetallized fuels, the contribution of convective heat transfer is more significant compared to the radiation. The increased heat transfer to the fuel surface evaporates more mass to the combustion zone, simultaneously the increased blowing from the surface decreases the temperature gradient at the surface, thus creating an additional blockage of blowing on convection heat transfer. Also, it is believed that the aggregation of metallic additives on the fuel surface during the fuel casting can reduce the heat release (Dermanci and Karabeyoglu 2015). Many metallic additives such as $\mathrm{Al}, \mathrm{B}, \mathrm{Mg}$, and $\mathrm{Zr}$ can generate three times higher heat of combustion than hydrocarbons (Gany 2006). However, the utilization of $\mathrm{Zr}$ as additive represents a severe limitation for actual high performance due to its molar mass and combustion. The heat of combustion study of the paraffin loaded with metallic additive is important to rate the preburn characterization for hybrid rocket applications. The flame temperature, which is directly related to specific impulse performance, fuel mass burn rate, regression rate, density specific impulse, and better combustion efficiency (where PE acts as plasticizer) can also be improved with the addition of the additives. These paraffin-based formulations could be a better choice for solid fuels in hybrid rocket applications.

\section{THEORETICAL PERFORMANCE AT 1 MPA}

Figure 5 shows the variation of flame temperature with $\mathrm{O} / \mathrm{F}$ for each solid fuel formulations. The addition of PE in paraffin wax increased the maximum flame temperature by $10^{\circ} \mathrm{C}$. Also, the addition of the $\mathrm{Al}$ and $\mathrm{B}$ additives by $25 \mathrm{wt} \%$ to $\mathrm{P} / \mathrm{PE}$ blend increases the maximum flame temperature by about 181 and $597^{\circ} \mathrm{C}$, respectively, when compared to pure paraffin wax. 


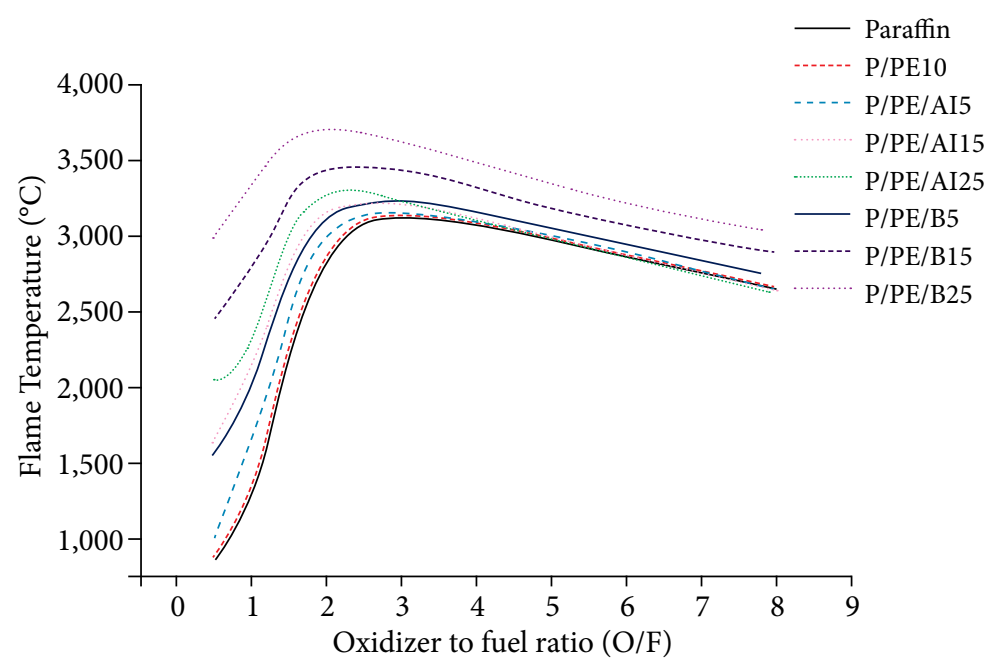

Figure 5. Flame temperature variations as a function of $\mathrm{O} / \mathrm{F}$ for various paraffin-based solid fuels at $1 \mathrm{MPa}$.

Figure 6 shows the variation of gravimetric specific impulse, $I_{\mathrm{sp}}$, with $\mathrm{O} / \mathrm{F}$ for all the paraffin-based solid fuel formulations. It is important to note that when $\mathrm{Al}$ loading varied from 5 to $25 \mathrm{wt} \%$ in paraffin wax, the specific impulse value is barely affected, whereas the addition of B shows a reverse trend (Table 7). Many researchers (Risha et al. 2002; Jaffe et al. 2013; Karabeyoglu and Arkun 2014; Thomas et al. 2015) have shown that addition of Al to polymeric and nonpolymeric solid fuel decreased the specific impulse. They attributed this behavior to a higher molecular weight of combustion products and the increased dissociation effect at high temperatures. Also, $\mathrm{B}$ has a lower molar mass than that of $\mathrm{Al}$ additive; this could have improved the specific impulse performance of B-based formulations. In this study, B loading increased from 5 to $25 \mathrm{wt} \%$, and $I_{\mathrm{sp}}$ increased about $47 \mathrm{~s}$. The increment in $I_{\text {sp }}$ is due to a higher flame temperature of $\mathrm{P} / \mathrm{PE} / \mathrm{B}$ formulation compared to other solid fuel formulations. In Table 4, it can be noted that the $\mathrm{P} / \mathrm{PE} / \mathrm{B}$ formulation delivered the highest volumetric specific impulse performance when compared to other fuel formulations. The addition of $\mathrm{Al}$ resulted in less improvement in volumetric and gravimetric specific impulse performance. The combustion of these fuels loaded with additives may form condensed combustion products (CCP), which expand through the nozzle, diminishing the specific impulse performance. Unfortunately, the CCP analysis was not performed in this study. However, the empirical correlations between specific impulse and CCP mass are discussed in some works in the literature (Maggi et al. 2010; 2012; DeLuca et al. 2010).

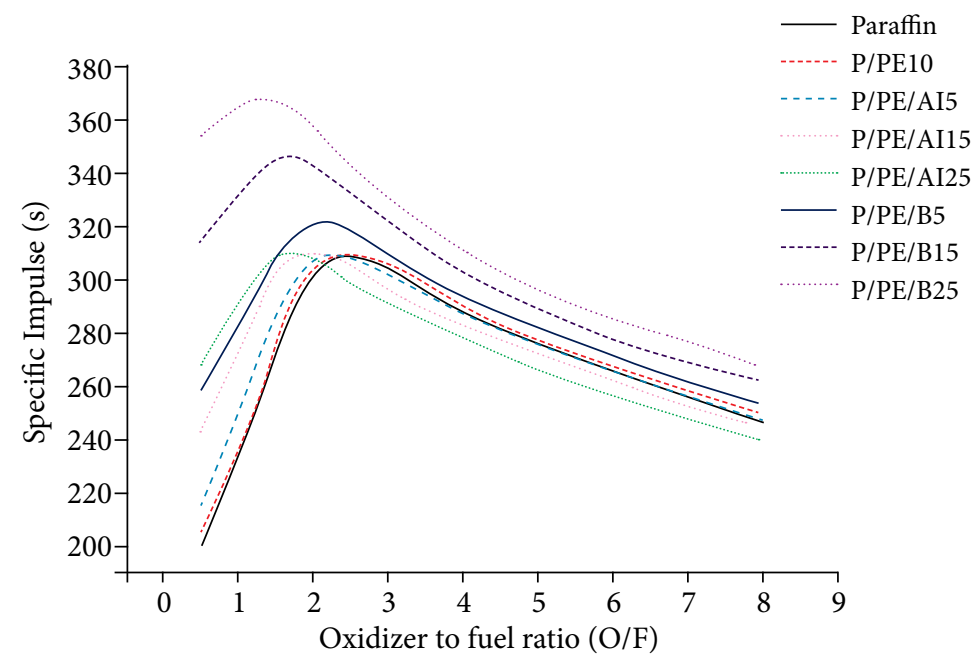

Figure 6. Gravimetric $l_{\mathrm{sp}}$ variations as a function of $\mathrm{O} / \mathrm{F}$ for various paraffin-based solid fuels at $1 \mathrm{MPa}$. 
Table 7. Maximum specific impulse and maximum flame temperature for various fuel Formulations.

\begin{tabular}{|c|c|c|c|c|c|}
\hline $\begin{array}{c}\text { Fuel } \\
\text { sample }\end{array}$ & {$[\mathbf{O} / \mathrm{F}]_{\max }$} & $\begin{array}{l}\text { Maximum flame } \\
\text { temperature }\left({ }^{\circ} \mathrm{C}\right]\end{array}$ & {$[\mathbf{O} / \mathbf{F}]_{\max }$} & $\begin{array}{l}\text { Maximum gravimetric } \\
\qquad \mathrm{I}_{\mathrm{sp}}[\mathbf{s}]\end{array}$ & $\begin{array}{l}\text { Maximum volumetric } \\
\qquad I_{\mathrm{sp}}\left[\mathrm{kg} \mathrm{s} / \mathrm{m}^{3}\right]\end{array}$ \\
\hline Paraffin & 3.0 & 3137 & 2.5 & 311 & $2.86 \times 10^{5}$ \\
\hline $\mathrm{P} / \mathrm{PE}$ & 3.0 & 3147 & 2.5 & 313 & $2.87 \times 10^{5}$ \\
\hline $\mathrm{P} / \mathrm{PE} / \mathrm{Al} 5$ & 3.0 & 3167 & 2.0 & 314 & $2.97 \times 10^{5}$ \\
\hline $\mathrm{P} / \mathrm{PE} / \mathrm{Al} 15$ & 2.5 & 3241 & 2.0 & 316 & $3.01 \times 10^{5}$ \\
\hline $\mathrm{P} / \mathrm{PE} / \mathrm{Al} 25$ & 2.0 & 3318 & 1.5 & 317 & $3.06 \times 10^{5}$ \\
\hline $\mathrm{P} / \mathrm{PE} / \mathrm{B} 5$ & 2.5 & 3255 & 2.1 & 326 & $3.09 \times 10^{5}$ \\
\hline $\mathrm{P} / \mathrm{PE} / \mathrm{B} 15$ & 2.0 & 3480 & 1.5 & 352 & $3.37 \times 10^{5}$ \\
\hline $\mathrm{P} / \mathrm{PE} / \mathrm{B} 25$ & 2.0 & 3734 & 1.4 & 372 & $3.60 \times 10^{5}$ \\
\hline
\end{tabular}

The $\mathrm{O} / \mathrm{F}$ ratio at which the maximum specific impulse occurs tends to shift to a lower value as metal additive added to paraffin formulation. Also, the $\mathrm{O} / \mathrm{F}$ ratio, where the maximum specific impulse occurred, is shifted to the lower value as compared to where the flame temperature attained maximum value. The dependency of specific impulse can explain this shift in $\mathrm{O} / \mathrm{F}$ on specific heat ratio, flame temperature, and molecular weight of combustion products (Fig. 7). The molecular weight of combustion products of paraffin-based formulations was also calculated, and it was increased as the O/F ratio increases.

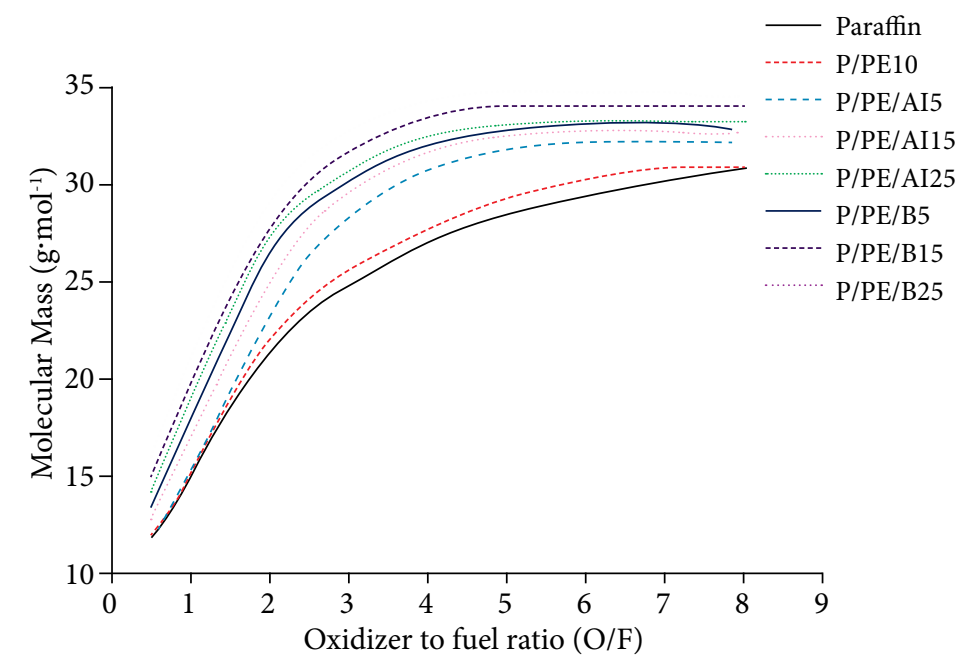

Figure 7. The molecular weight of combustion products variation as a function of $\mathrm{O} / \mathrm{F}$ for various paraffin-based solid fuels at $1 \mathrm{MPa}$.

The solid fuel performance can also be predicted by evaluating the characteristics velocity $\left(C^{\star}\right)$ as a function of the $\mathrm{O} / \mathrm{F}$ ratio (Davis and Yilmaz 2014). Figure 8 shows the characteristics velocity for various paraffin-based solid fuels. The P/PE/B formulation shows a maximum value of $C^{\star}$ compared to other paraffin-based fuel formulations. It is important to note that the addition of $B$ to paraffin achieved a higher value of $C^{\star}$ at a low $\mathrm{O} / \mathrm{F}$ ratio compared to that of $\mathrm{Al}$ formulation. The $\mathrm{P} / \mathrm{PE} / \mathrm{B}$ formulation has a lower value of $(\mathrm{O} / \mathrm{F})_{\text {max }}$ at which the specific impulse and flame temperature are maximum. The high performance can be achieved due to the improved combustion temperature as well as the lower $\mathrm{O} / \mathrm{F}$ ratio. The lower $\mathrm{O} / \mathrm{F}$ ratio allows for a smaller, lighter oxidizer tank (Maharaj et al. 2016). Also, from the oxidizer standpoint, the liquid oxidizer will require a larger tank, and larger the oxidizer tank, the larger the structural mass. $\mathrm{P} / \mathrm{PE} / \mathrm{Al}$ formulations have a higher value of optimum $\mathrm{O} / \mathrm{F}$ ratio, and density compare to $\mathrm{P} / \mathrm{PE} / \mathrm{B}$ formulations. Therefore, $\mathrm{P} / \mathrm{PE} / \mathrm{Al}$ fuel formulations can mitigate the rocket structural mass penalty associated with a lower optimum $\mathrm{O} / \mathrm{F}$ ratio. 


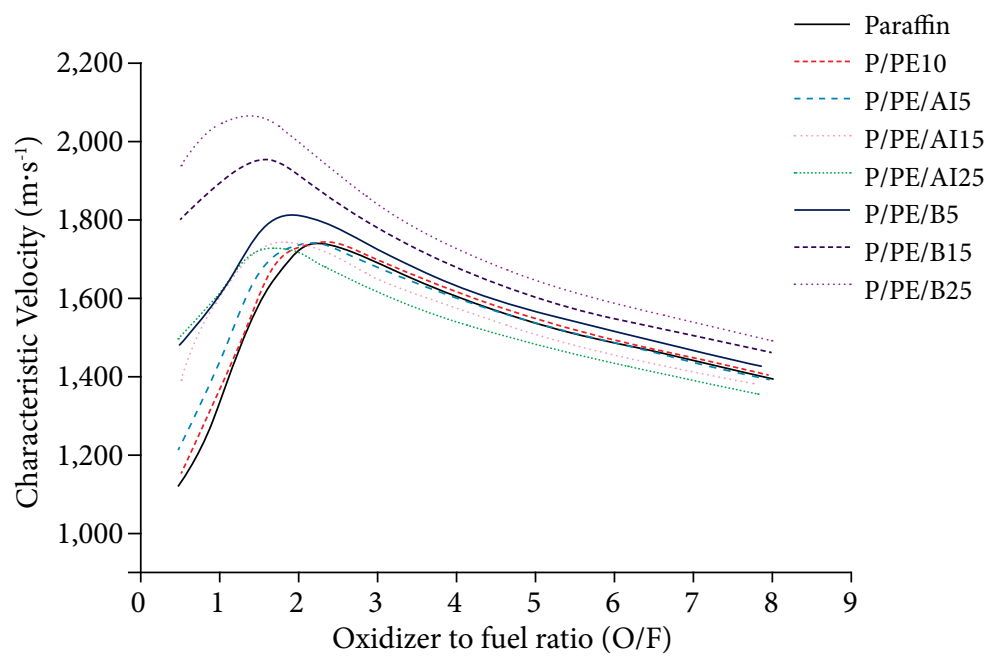

Figure 8. Characteristic velocity variations as a function of $\mathrm{O} / \mathrm{F}$ for various paraffin-based solid fuels at $1 \mathrm{MPa}$.

The theoretical study can only provide a general indication of solid fuel performance. For reliable assessment, lab-scale ballistic motor tests must be performed to evaluate the real-time performance parameters. The actual specific impulse and characteristic velocity performance of paraffin solid fuels with metal additives depend on several factors, such as multiphase losses and throat erosion in the nozzle. Moreover, the CEA code only simulated thermochemical effects and could not take into account physical phenomena such as fuel droplet entrainment, which in fact affect considerably the paraffin combustion process. The mass burning rate of paraffin-based fuels highly depends on the entrainment mass transfer process during combustion.

Moreover, CEA assumes a perfect mixing of fuel and oxidizer, while the turbulent boundary layer combustion is ruled by diffusion in real hybrid rocket combustion. The oxidizer vapor diffuses toward fuel vapor from the core flow region via turbulent diffusion. Therefore, the combustion process in the actual scenario will lead to predicting a different performance than that of CEA. Unfortunately, in this study, these critical factors are challenging to estimate theoretically and require an experimental lab-scale motor testing for authentic assessment. Based on this study, future lab-scale testing should involve the evaluation of performance parameters such as specific impulse, solid fuel regression rate, thrust, and combustion efficiencies of these paraffin-based solid fuels.

\section{THEORETICAL PERFORMANCE AT 3 MPA}

To simulate the lab-scale motor test condition, CEA calculations were performed at a combustion chamber pressure of $3 \mathrm{MPa}$. The flame temperature and specific impulse variation with O/F ratio are shown in Fig. 9 and Fig. 10, respectively, which followed a similar trend as observed at $1 \mathrm{MPa}$ chamber pressure. The similar trends of the flame temperature and specific impulse curve can be observed at $3 \mathrm{MPa}$ as in the data at $1 \mathrm{MPa}$. As the combustion chamber pressure increases from 1 to $3 \mathrm{MPa}$, the maximum flame temperature for pure paraffin increased about $163^{\circ} \mathrm{C}$, whereas $\mathrm{P} / \mathrm{PE} / \mathrm{Al}$ and $\mathrm{P} / \mathrm{PE} / \mathrm{B}$ formulation with $25 \%$ additive loading show an increment of about 180 and $247^{\circ} \mathrm{C}$, respectively. The specific impulse improvement for pure paraffin wax is about $4 \mathrm{~s}$ while the $\mathrm{P} / \mathrm{PE} / \mathrm{Al}$ and $\mathrm{P} / \mathrm{PE} / \mathrm{B}$ formulations show a maximum increment of 3 and $5 \mathrm{~s}$, respectively. Increments in specific impulse and flame temperatures are trivial when compared to the significant increase in combustion chamber pressure. Thus, it can be concluded that the performance parameters are independent of combustion chamber pressure.

The characteristics velocity curves of eight paraffin-based solid fuel formulations were simulated and are present in Fig. 11. It is shown that $\mathrm{P} / \mathrm{PE} / \mathrm{B} 25$ has the highest characteristic velocity value of $2116 \mathrm{~m} / \mathrm{s}$ at the smallest optimum $\mathrm{O} / \mathrm{F}$ ratio of 1.4 . At the same optimum $\mathrm{O} / \mathrm{F}$ ratio, the $\mathrm{P} / \mathrm{PE} / \mathrm{Al} 25$ formulation has a lower characteristic velocity value compared to the $\mathrm{P} / \mathrm{PE} / \mathrm{B} 25$ formulation. It indicates that the energy performance of the $\mathrm{P} / \mathrm{PE} / \mathrm{B}$ based fuel formulation is high compared to other combinations. The addition of metallic additives to the paraffin wax fuel has enhanced the solid fuel energy performance. The P/PE/B fuel formulation can be an attractive alternative solid fuel combination for hybrid rocket and ramjet propulsion system. 


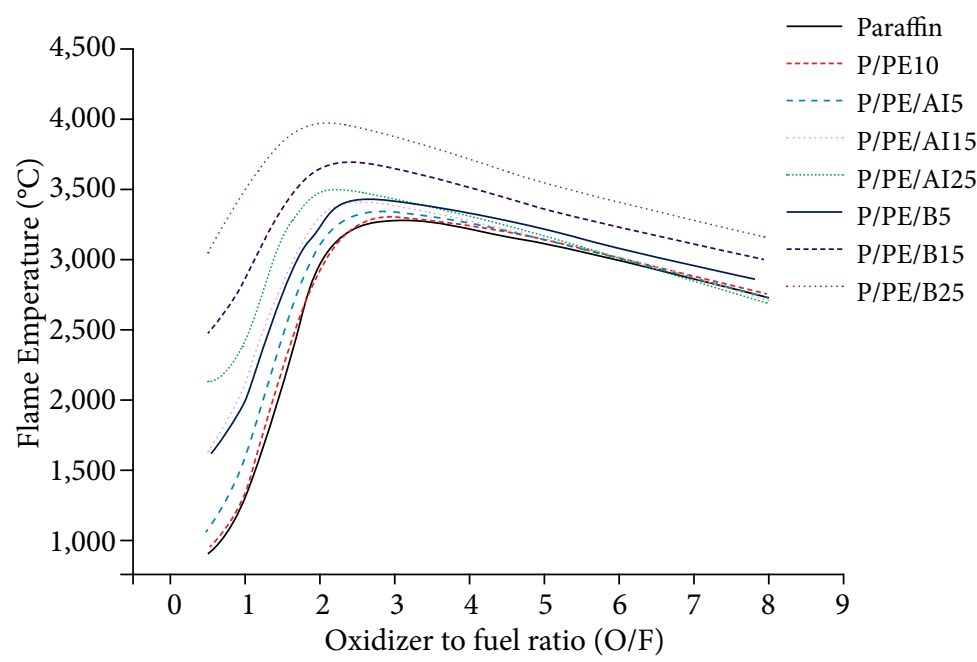

Figure 9. Flame temperature variations as a function of O/F for various paraffin-based solid fuels at $3 \mathrm{MPa}$.

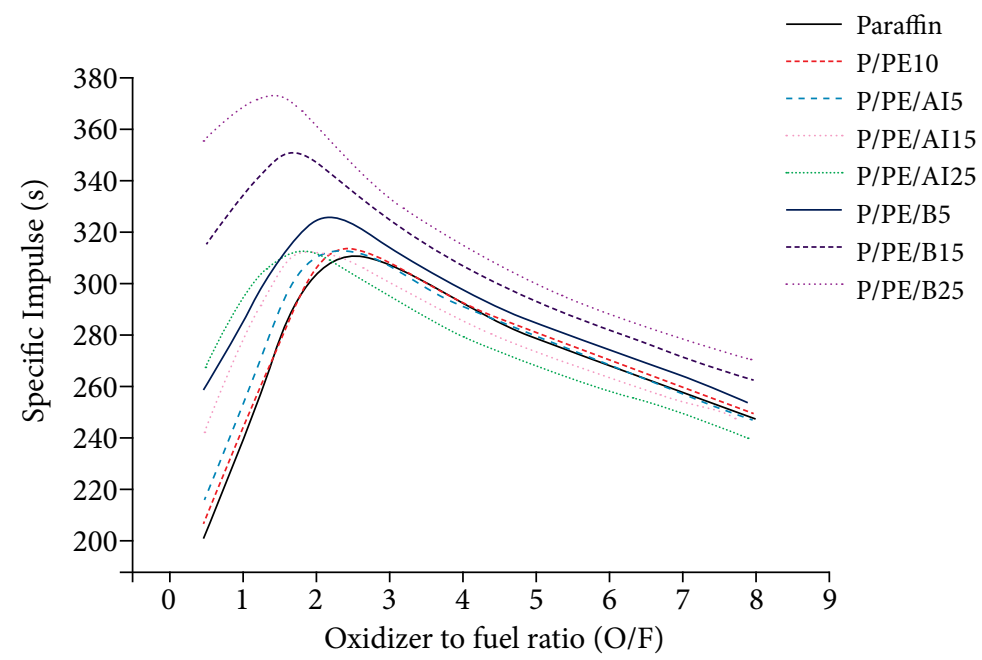

Figure 10. Specific Impulse variations as a function of O/F for various paraffin-based solid fuels at $3 \mathrm{MPa}$.

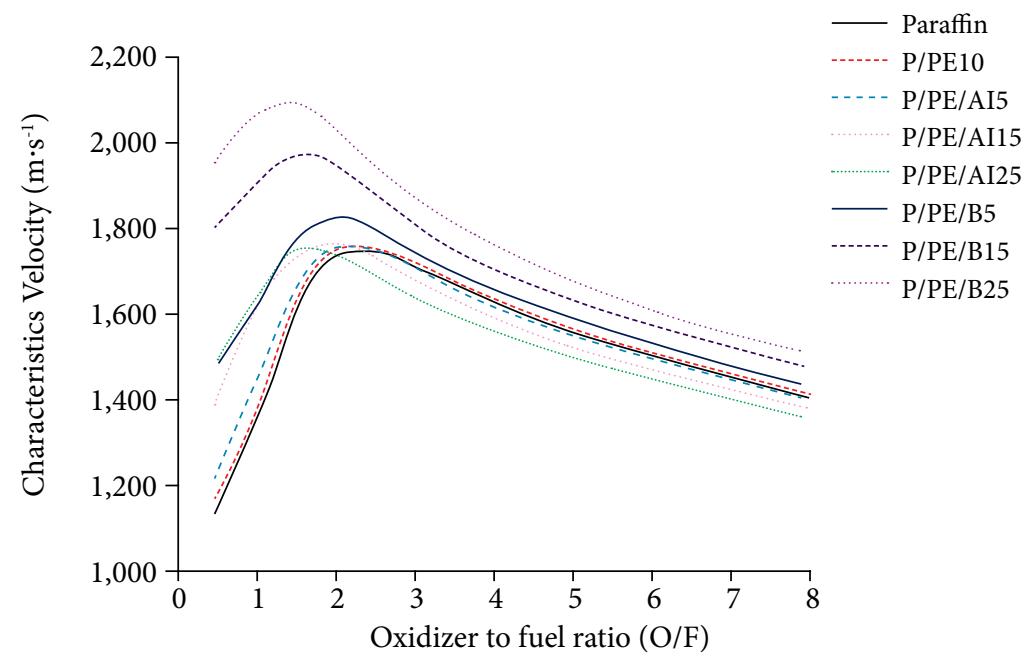

Figure 11. Characteristic velocity variations as a function of $\mathrm{O} / \mathrm{F}$ for various paraffin-based solid fuels at $3 \mathrm{MPa}$. 


\title{
CONCLUSION
}

In this study, the heat of combustion and theoretical performance of the paraffin fuel loaded with $\mathrm{Al}$ and $\mathrm{B}$ additives were analyzed. The heat of combustion of these solid fuels was studied using an adiabatic bomb calorimeter. The addition of $\mathrm{Al}$ and $\mathrm{B}$ additives increased the heat of combustion of the paraffin-based fuels. Solid fuel containing the Al additive showed higher heat of combustion compared to the $\mathrm{B}$ loaded fuels. The reason for this is believed to poor combustion of B particles at low temperatures and pressure conditions.

The CEA results showed that the addition of $\mathrm{Al}$ is not effective in improving the specific impulse for $\mathrm{P} / \mathrm{PE} / \mathrm{Al}$ formulation. However, the P/PE/B formulation at $25 \mathrm{wt} \% \mathrm{~B}$ loading has delivered a specific impulse of about $372 \mathrm{~s}$. Boron-containing fuels have a significant advantage over Al-containing fuel formulations in terms of specific impulse. Furthermore, it has shown that the optimum $\mathrm{O} / \mathrm{F}$ shifted to lower values as the metal additive loaded in the fuel. This might be beneficial for specific application areas such as the space mission, which demanding less oxidizer tank volume (more payloads). Theoretical performance predicted in this paper has not considered the actual multiphase losses, erosion in the nozzle, and paraffin droplets entrainment process, which can even affect the performance appreciably. Therefore, to predict the actual performance of these paraffin-based fuels, a detailed experimental assessment is required.

\section{ACKNOWLEDGMENTS}

The authors thank the Hindustan Institute of Technology and Science for the help on experimental resources and funding for supporting this project.

Editors and authors are thankful to Fundação Conrado Wessel for providing the financial support for publishing this article.

\section{FUNDING}

There is no funder to report.

\section{AUTHOR'S CONTRIBUTION}

Conceptualization: Pal Y.; Investigation: Gopalakrishnan K.; Writing - Original Draft: Pal Y. and Raja A.; Writing - Review and Editing: Gopalakrishnan K. and Pal Y.; Supervision: Pal Y.

\section{REFERENCES}

\begin{abstract}
Altman D, Holzman A (2007) Overview and history of hybrid rocket propulsion. In: Kuo KK, Chiaverini MJ, editors. Fundamentals of hybrid rocket combustion and propulsion. p. 1-36. Reston: AlAA. https://doi.org/10.2514/5.9781600866876.0001.0036

ASTM (2019) ASTM D240 - 19 Standard test method for heat of combustion of liquid hydrocarbon fuels by bomb calorimeter. West Conshohocken: ASTM International. [accessed Nov 21 2019]. DOl:10.1520/D0240-19.

Azevedo VA, Alves I, Shynkarenko O, Veras CAG (2019) Experimental investigation of high regression rate paraffin for solid fuel ramjet propulsion. Paper presented AIAA Propulsion and Energy 2019 Forum. AIAA; Indianapolis, Indiana, USA. https://doi. org/10.2514/6.2019-3984
\end{abstract}

Cantwell B, Karabeyoglu A, Altman D (2010) Recent advances in hybrid propulsion. Int J Energetic Mater Chem Propul 9(4):305-326. https://doi.org/10.1615/IntJEnergeticMaterialsChemProp.v9.i4.20 
Carmicino C, Scaramuzzino F, Sorge AR (2014) Trade-off between paraffin-based and aluminium-loaded HTPB fuels to improve performance of hybrid rocket fed with $\mathrm{N}_{2}$ O. Aerosp Sci Technol 37:81-92. https://doi.org/10.1016/j.ast.2014.05.010

Chen S, Tang Y, Zhang W, Shen R, Yu H, Ye Y, DeLuca LT (2019) Innovative methods to enhance the combustion properties of solid fuels for hybrid rocket propulsion. Aerospace 6(4):47. https://doi.org/10.3390/aerospace6040047

Connell Junior TL, Risha GA, Yetter RA, Roberts CW, Young G (2013) Combustion of boron and fluorocarbon solid fuels in a hybrid rocket. Paper presented 49th AIAA/ASME/SAE/ASEE Joint Propulsion Conference. AIAA; San Jose, California, USA. https://doi. org/10.2514/6.2013-3970

Davis SM, Yilmaz N (2014) Thermochemical analysis of hypergolic propellants based on triethylaluminum/nitrous oxide. Int $\mathrm{J}$ Aerosp Eng 2014:269836. https://doi.org/10.1155/2014/269836

DeLuca LT, Galfetti L, Colombo G, Maggi F, Bandera A, Babuk VA, Sinditskii VP (2010) Microstructure effects in aluminized solid rocket propellants. J Propuls Power 26(4):724-732. https://doi.org/10.2514/1.45262

Dermanci 0, Karabeyoglu AM (2015) Effect of nano particle addition on the regression rate of liquefying fuels. Paper presented 51st AIAA/SAE/ASEE Joint Propulsion Conference. AIAA; Orlando, Florida, USA. https://doi.org/10.2514/6.2015-4139

DeSain JD, Brady BB, Metzler KM, Curtiss TJ, Albright TV (2009) Tensile tests of paraffin wax for hybrid rocket fuel grains. Paper presented 45th AIAA/ASME/SAE/ASEE Joint Propulsion Conference \& Exhibit. AIAA; Denver, Colorado, USA. https://doi.org/10.2514/6.20095115

Di Martino GD, Gallo G, Mungiguerra S, Carmicino C, Savino R, Cardillo D, Battista F (2019) Recent advancements in experimental and numerical characterization of paraffin-based fuels for hybrid rocket application. Paper presented AIAA Propulsion and Energy 2019 Forum. AIAA; Indianapolis, Indiana, USA. https://doi.org/10.2514/6.2019-4195

Evans B, Favorito NA, Boyer JE (2007) Characterization of solid fuel mass-burning enhancement utilizing an X-ray translucent hybrid rocket motor. Int J Energetic Mater Chem Propul 6(6)713-732. https://doi.org/10.1615/IntJEnergeticMaterialsChemProp.v6.i6.40

Gany A (2006) Effect of fuel properties on the specific thrust of a ramjet engine. Def Sci J 56(3):321-328.

Gany A (2014) Thermodynamic limitation on boron energy realization in ramjet propulsion. Acta Astronaut 98:128-132. https://doi. org/10.1016/j.actaastro.2014.01.023

Grosse M (2009) Effect of a diaphragm on performance and fuel regression of a laboratory scale hybrid rocket motor using nitrous oxide and paraffin. Paper presented 45th AIAA/ASME/SAE/ASEE Joint Propulsion Conference \& Exhibit. AIAA; Denver, Colorado, USA. https://doi.org/10.2514/6.2009-5113

Jaffe RL, Karabeyoglu AM, Evans BJ, Zilliac G, Sherburn MS (2013) Characterization and evaluation of high energy hydrocarbon additives for paraffin-fuel hybrid rockets. Paper presented 49th AIAA/ASME/SAE/ASEE Joint Propulsion Conference. AIAA; San Jose, California, USA. https://doi.org/10.2514/6.2013-3968

Jawale LS, Dey MC, Gupta M, Bhattacharya B (2013) Effect of experiment environment on calorimetric value of composite solid propellants. Def Sci J 63(5):467-472.

Jiawang Y, Linshuang Z, Zhiming D, Qifeng X, Zhihua Z (2014) Study on combustion heat of pyrotechnics. Procedia Eng 84:849-853. https://doi.org/10.1016/j.proeng.2014.10.505

Karabeyoglu M, Cantwell B, Altman D (2001) Development and testing of paraffin-based hybrid rocket fuels. Paper presented 37th Joint Propulsion Conference and Exhibit. AIAA; Salt Lake City, Utah, USA. https://doi.org/10.2514/6.2001-4503

Karabeyoglu A, Zilliac G, Cantwell BJ, DeZilwa S, Castellucci P (2004) Scale-up tests of high regression rate paraffin-based hybrid rocket fuels. J Propuls Power 20(6):1037-1045. https://doi.org/10.2514/1.3340

Karabeyoglu AM, Arkun U (2014) Evaluation of fuel additives for hybrid rockets and SFRJ systems. Paper presented 5Oth AIAA/ASME/ SAE/ASEE Joint Propulsion Conference. AIAA; Cleveland. Ohio, USA. https://doi.org/10.2514/6.2014-3647

Kim S, Moon H, Kim J (2015) Thermal characterizations of the paraffin wax/low density polyethylene blends as a solid fuel. Thermochim Acta 613:9-16. https://doi.org/10.1016/j.tca.2015.05.016

Kishore K, Pai Verneker VR, Begum AS (1982) Calorimetric values of composite solid propellants. Thermochim Acta 54(1-2):141-146. https://doi.org/10.1016/0040-6031(82)85072-7

Kishore K, Sankaralingam S, Begum AS (1986) Changes in the calorimetric value and ignition temperature of composite solid propellants during ageing - A note. Def Sci J 36(4):425-428.

Kobald M, Ciezki HK, Schlechtriem S, Toson E, De Luca L (2014) Evaluation of paraffin-based fuels for hybrid rocket engines. Paper presented 50th AIAA/ASME/SAE/ASEE Joint Propulsion Conference. AIAA; Cleveland. Ohio, USA. https://doi. org/10.2514/6.2014-3646

Kumar R, Ramakrishna PA (2016) Studies on EVA-based wax fuel for launch vehicle applications. Propellants Explos Pyrotech 41(2):295303. https://doi.org/10.1002/prep.201500172 
Larson C, Pfeil K, DeRose M, Garrick P (1996) High pressure combustion of cryogenic solid fuels for hybrid rockets. Paper presented 32nd Joint Propulsion Conference and Exhibit. AIAA; Lake Buena Vista, Florida, USA. https://doi.org/10.2514/6.1996-2594

Maggi F, Bandera A, Galfetti L, DeLuca LT Jackson TL (2010) Efficient solid rocket propulsion for access to space. Acta Astronaut 66(1112):1563-1573. https://doi.org/10.1016/j.actaastro.2009.10.012

Maggi F, Gariani G, Galfetti L, DeLuca LT (2012) Theoretical analysis of hydrides in solid and hybrid rocket propulsion. Int J Hydrog Energy 37(2):1760-1769. https://doi.org/10.1016/j.ijhydene.2011.10.018

Maharaj CS, Veale KL, Pitot J, Bemont C (2016) Development of a $75 \mathrm{~mm}$ Hybrid rocket motor to test metal additives. Paper presented 52nd AIAA/SAE/ASEE Joint Propulsion Conference. AIAA; Salt Lake City, Utah, USA. https://doi.org/10.2514/6.2016-4863

Maruyama S, Ishiguro T, Shinohara K, Nakagawa I (2011) Study on mechanical characteristics of paraffin-based fuel. Paper presented 47th AIAA/ASME/SAE/ASEE Joint Propulsion Conference \& Exhibit. AIAA; San Diego, California, USA. https://doi. org/10.2514/6.2011-5678

Mazzetti A, Merotto L, Pinarello G (2016) Paraffin-based hybrid rocket engines applications: A review and a market perspective. Acta Astronaut 126:286-297. https://doi.org/10.1016/j.actaastro.2016.04.036

McBride BJ, Gordon S (1996) Computer program for calculation of complex chemical equilibrium compositions and applications II.: Users' manual and program description. Washington: NASA. [accessed Nov 21 2019.]. https://ntrs.nasa.gov/citations/19960044559

Pal Y, Ravikumar V (2019) Mechanical characterization of paraffin-based hybrid rocket fuels. Mater Today 16(2):939-948. https://doi. org/10.1016/j.matpr.2019.05.180

Paravan C, Verga A, Maggi F, Galfetti L (2019) Accelerated ageing of micron- and nano-sized aluminum powders: Metal content, composition and non-isothermal oxidation reactivity. Acta Astronaut 158:397-406. https://doi.org/10.1016/j.actaastro.2018.08.001

Risha GA, Boyer E, Wehrman RB, Kuo KK (2002) Performance comparison of HTPB-based solid fuels containing nano-sized energetic powder in a cylindrical hybrid rocket motor. Paper presented 38th AIAA/ASME/SAE/ASEE Joint Propulsion Conference \& Exhibit. AIAA; Indianapolis, Indiana, USA. https://doi.org/10.2514/6.2002-3576

Risha GA, Evans BJ, Boyer E, Wehrman RB, Kuo KK (2003) Nano-sized aluminum and boron-based solid fuel characterization in a hybrid rocket engine. Paper presented 39th AIAA/ASME/SAE/ASEE Joint Propulsion Conference and Exhibit. AIAA; Huntsville, Alabama, USA. https://doi.org/10.2514/6.2003-4593

Shark SC, Pourpoint TL, Son SF, Heister SD (2013) Performance of dicyclopentadiene $/ \mathrm{H}_{2} \mathrm{O}_{2}$-based hybrid rocket motors with metal hydride additives. J Propul Power 29(5):1122-1129. https://doi.org/10.2514/1.B34867

Sutton GP, Biblarz $\mathrm{O}$ (2000) Rocket propulsion elements: an introduction to the engineering of rockets. New York: John Wiley \& Sons.

Tang Y, Chen S, Zhang W, Shen R, DeLuca LT, Ye Y (2017) Mechanical modifications of paraffin-based fuels and the effects on combustion performance. Propellants Explos Pyrotech 42(11):1268-1277. https://doi.org/10.1002/prep.201700136

Thomas JC, Petersen EL, DeSain JD, Brady BB (2015) Hybrid rocket enhancement by micro- and nano-scale additives in HTPB fuel grains. Paper presented 51st AIAA/SAE/ASEE Joint Propulsion Conference. AIAA; Orlando, Florida, USA. https://doi. org/10.2514/6.2015-4041

Veale K, Adali S, Pitot J, Brooks M (2017) A review of the performance and structural considerations of paraffin wax hybrid rocket fuels with additives. Acta Astronaut 141:196-208. https://doi.org/10.1016/j.actaastro.2017.10.012

Walters RN, Hackett SM, Lyon RE (2000) Heats of combustion of high temperature polymers. Fire Mater 24(5):245-252. https://doi. org/10.1002/1099-1018(200009/10)24:5<245::AID-FAM744>3.0.C0;2-7

Wang J, Severtson SJ, Stein A (2006) Significant and concurrent enhancement of stiffness, strength and toughness for paraffin wax through organoclay addition. Adv Mater 18(12):1585-1588. https://doi.org/10.1002/adma.200502615

Whitmore S, Peterson Z, Eilers S (2011) Analytical and experimental comparisons of HTPB and ABS as hybrid rocket fuels. Paper presented 47th AIAA/ASME/SAE/ASEE Joint Propulsion Conference \& Exhibit. AIAA; San Diego, California, USA. https://doi. org/10.2514/6.2011-5909 